\title{
Somerset County Flood Information System
}

The timely warning of a flood is crucial to the protection of lives and property. One has only to recall the floods of August 2, 1973, September 16 and 17, 1999, and April 16, 2007, in Somerset County, New Jersey, in which lives were lost and major property damage occurred, to realize how costly, especially in terms of human life, an unexpected flood can be. Accurate forecasts and warnings cannot be made, however, without detailed information about precipitation and streamflow in the drainage basin.

Since the mid 1960's, the National Weather Service (NWS) has been able to forecast flooding on larger streams in Somerset County, such as the Raritan and Millstone Rivers. Flooding on smaller streams in urban areas was more difficult to predict. In response to this problem the NWS, in cooperation with the Green Brook Flood Control Commission, installed a precipitation gage in North Plainfield, and two flash-flood alarms, one on Green Brook at Seeley Mills and one on Stony Brook at Watchung, in the early 1970's.

In 1978, New Jersey's first countywide flood-warning system was installed by the U.S. Geological Survey (USGS) in Somerset County. This system consisted of a network of eight stage and discharge gages equipped with precipitation gages linked by telephone telemetry and eight auxiliary precipitation gages. The gages were installed throughout the county to collect precipitation and runoff data that could be used to improve flood-monitoring capabilities and flood-frequency estimates.

Recognizing the need for more detailed hydrologic information for Somerset County, the USGS, in cooperation with Somerset County, designed and installed the Somerset County Flood Information System (SCFIS) in 1990. This system is part of a statewide network of stream gages, precipitation gages, weather stations, and tide gages that collect data in real time. The data provided by the SCFIS improve the flood forecasting ability of the NWS and aid Somerset County and municipal agencies in the planning and execution of flood-preparation and emergency-evacuation procedures in the county. This fact sheet describes the SCFIS and identifies its benefits.

\section{DESCRIPTION OF THE STUDY AREA}

Somerset County (fig. 1), located in central New Jersey, covers an area of 305 square miles and is home to a population of more than 300,000 . The county, which is divided into northern and southern halves by the Raritan River, encompasses 21 municipalities, and is part of the most populous metropolitan area in the United States.

\section{COLLECTING HYDROLOGIC DATA}

Information needed for flood forecasting includes stream stage (the height of the water level in the stream above an arbitrary datum) and the amount and distribution of precipitation. The gages in the SCFIS system automatically measure stage at 15-minute intervals, store the data, and transmit the data to a network of computer base stations and the World Wide Web (WWW). Some of the gages also transmit the data by telephone to specific critical decision-making centers. The stage data at many of the gages also are used to compute the discharge (the volume of water that flows past a point on the stream during a specific time interval, typically measured in cubic feet per second) using an established relationship between stage and discharge, referred to as a rating curve. The rating curves are developed by USGS personnel who routinely visit the gages to measure discharge under a variety of flow conditions. The rating curve also allows stage to be determined from an estimate of discharge.

Precipitation gages distributed throughout the drainage basin are used to measure and record the amount of precipitation that falls during a given storm. These gages also store and transmit data using the same modes of telemetry as the stage gages. This information, together with data from the National Oceanic and Atmospheric Administration's (NOAA) NWS Doppler radar, allows the amount and distribution of precipitation to be accurately estimated. From this precipitation estimate, as well as an estimate of water coming from other sources such as local runoff, discharge at a given location can be predicted and converted to an estimate of stage.

\section{SOMERSET COUNTY FLOOD INFORMATION SYSTEM}

In the early 1990's, the USGS replaced the telephone telemetry of the first network with VHF-radio links between the gages and the base-station computers. During the same period, 5 stage-only gages and 10 precipitation gages, as well as connections to the Passaic Flood Warning System (PFWS) and 5 additional NWS stage and discharge gages, were added to the network. The new stage and discharge gages were placed at critical flood-prone locations to provide real-time indications of imminent flooding. The additional precipitation gages were installed throughout the county to provide much-needed information on the spatial distribution of precipitation, especially heavy rainfall. In 1996 and 1997 the system was adjusted further; some gages were added, and others were removed. The system is continually adapted as changes are needed and technology evolves. 


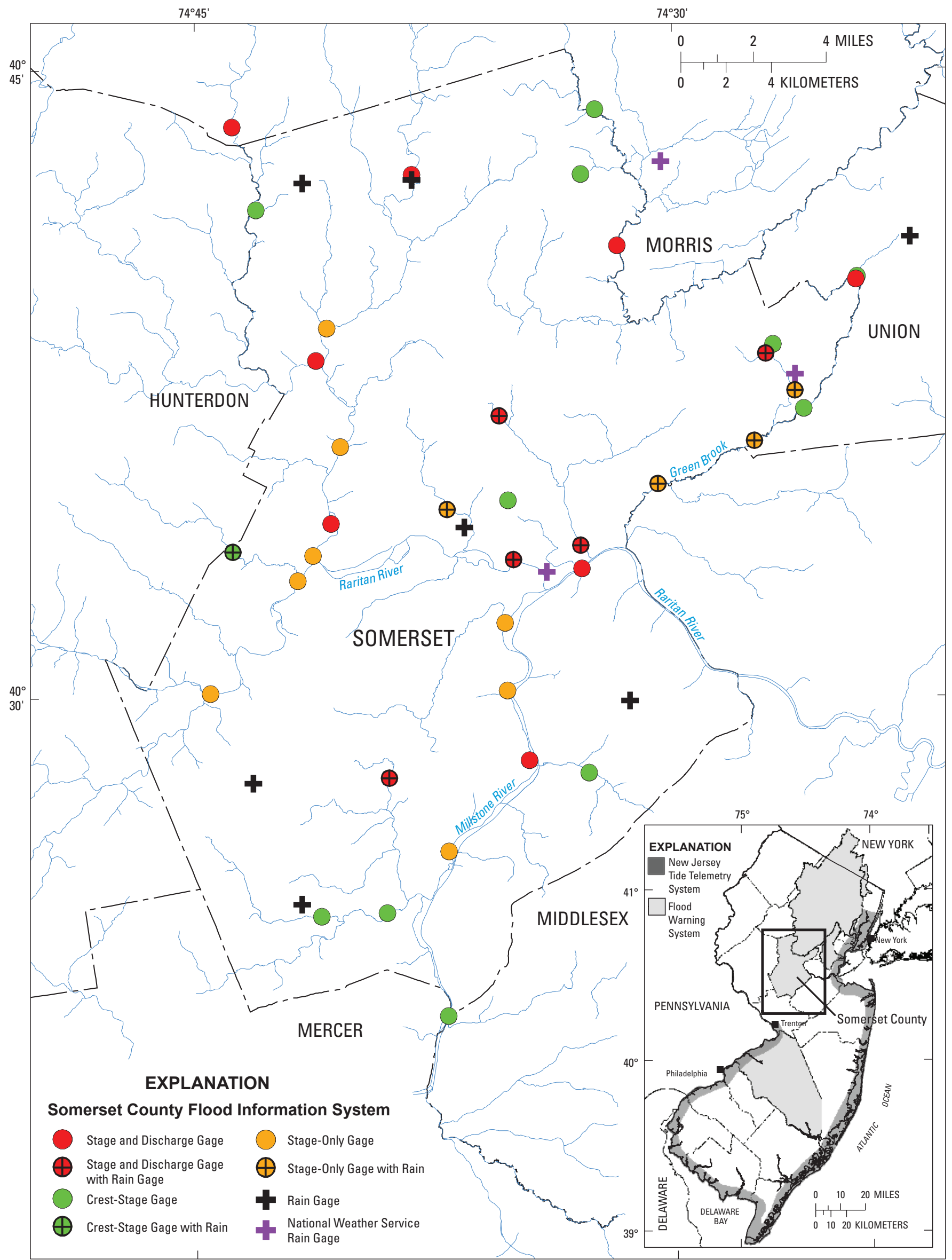

Figure 1. Locations of gages in the Somerset County Flood Information System, Somerset County, New Jersey and vicinity. 


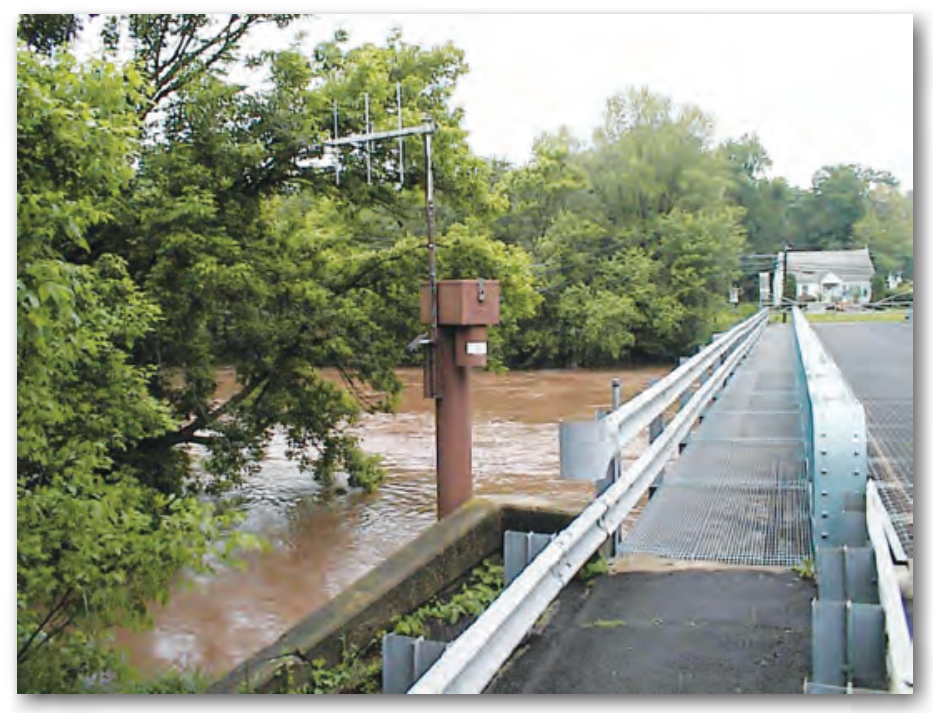

Figure 2. Flooding at U.S. Geological Survey stream gage 01398102 on the South Branch Raritan River at South Branch, New Jersey.

The SCFIS presently (2007)consists of 13 stage and discharge gages, 12 stage-only gages, 19 precipitation gages (8 co-located with stream gages), and 12 crest-stage gages (1 co-located with a precipitation gage) (figs. 1-3). The stage, discharge, and precipitation are automatically measured at 15-minute intervals, stored by the data collection platform (DCP), and transmitted by the NOAA GOES (Geostationary Operational Environmental Satellite) satellite to a network of computer base stations and the WWW. The data also are transmitted by telephone to computer base stations located at the Somerset County Engineering Division in the Somerset County administration building in Somerville, N.J.; the NWS office in Mount Holly, N.J.; and the USGS New Jersey Water Science Center in West Trenton, N.J. The data, as well as additional information from the National Weather Service, are monitored continuously. Software programs on the computer base stations collect the data and send alarms and messages by cell phone and pager to Somerset County personnel who monitor the system 24 hours a day, 7 days a week. Watches and warnings, as well as specific flood information, are transmitted as facsimile (fax) to police, fire departments, rescue squads, and emergency managers. The timely transmittal of this information allows emergency personnel to warn residents about flooding in order to prevent loss of life and property. Although these messages are intended only for first responders, residents can subscribe to receive watch and warning information by e-mail through Somerset County's use of the GovDelivery system at http:// service.govdelivery.com/service/partner.html? code $=$ NJSOMER. The crest-stage gages-simple, non-mechanical devices that can only be read manually - record peak-stage levels between inspections. These gages provide redundancy during primary sensor failure as well as verification of recorded peaks.

\section{LINKS WITH OTHER SYSTEMS}

At present (2007), five local flood-warning systems, in addition to the SCFIS, are in operation in New Jersey--the Burlington County Flood Warning System (BCFWS), the Pascack
Brook Flood Warning System (PBFWS), the Passaic Flood Warning System (PFWS), the Rahway River Flood Warning System (RRFWS), and the New Jersey Tide Telemetry System (NJTTS) (fig. 1 inset).

The BCFWS, portions of which have been in use since 1964, includes 10 stream and 3 precipitation gages to monitor stream levels and rainfall in Burlington County; the PBFWS, in use since 1998, includes 4 stream and 3 precipitation gages to monitor the Pascack Brook Basin; the PFWS, in use since 1903, includes 21 stream and 35 precipitation gages to monitor the Passaic River Basin; the RRFWS, in use since 1964, includes 7 stream and 3 precipitation gages to monitor the Rahway River Basin; and the NJTTS, in use since 1997, includes 20 tide gages, 5 tide/weather stations, and 31 tidal crest-stage gages to monitor the coastal regions in 13 New Jersey counties. Each system consists of automated stream gages, tide gages, weather stations, and precipitation gages from which data are transmitted to computer base stations located throughout the State and the WWW by telephone, radio, and (or) satellite link.

\section{BENEFITS OF THE SOMERSET COUNTY FLOOD INFORMATION SYSTEM}

The SCFIS provides valuable information that benefits residents of Somerset County, the State of New Jersey, and Federal agencies that regulate the county's waterways.

- The hydrologic data collected aid the NWS in developing timely and accurate flood forecasts.

- The availability of real-time stage, discharge, and precipitation data, along with the NWS severe weather and flood forecasts, watches, and warnings, allow the State, county, and high-risk municipalities to develop efficient emergency evacuation procedures.

- The real-time stage and discharge data could be used in conjunction with other time-of-travel data as part of an earlyresponse system for hazardous-waste spills. Such a system

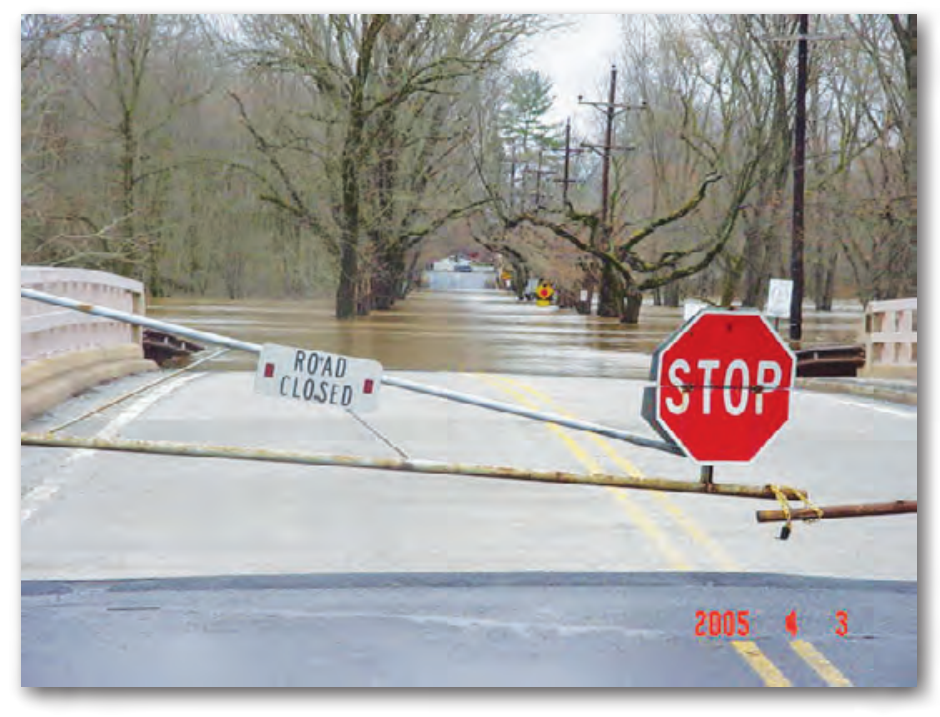

Figure 3. Flooding at U.S. Geological Survey stream gage 01402000 on the Millstone River at Blackwells Mills, New Jersey. 
would give emergency-response agencies and water-supply utilities a tool to plan actions in accordance with the location of the spill.

- Real-time knowledge of stage and discharge can allow commercial businesses and industries to take actions to reduce inventory and structural losses during a storm.

- The hydrologic data collected can be used to optimize the design and operation of dams, levees, bridges, and water- and wastewater-treatment facilities.

- The hydrologic data collected can be used to plan future public water supplies, assist in monitoring water quality, and aid in the assessment of the effects of environmental regulations.

- The public and private sectors can use the data for developmental and environmental concerns.

\section{ACCESS TO THE DATA}

The stage, discharge, and precipitation data from this network, as well as data from gages that are part of the New Jersey statewide system, can be accessed on the WWW at the USGS New Jersey Water Science Center homepage at http://nj.usgs. gov/ under the heading "Real-Time Data". A hydrograph of the stage, discharge, and precipitation data for up to the last 31 days (fig. 4) is available by clicking on a specific station. These data also are available on NOAA's NWS Advanced Hydrologic Prediction Service (AHPS) website at http://www.weather.gov/ ahps/. Real-time flood-warning data that are not transmitted by satellite, but rather by radio telemetry on an event-reporting basis, can be viewed at the Automated Flood Warning Systems web site at http://www.afws.net/.
A new mode of accessing data from USGS real-time stations is through USGS StreamMail. This service provides immediate water information from the USGS Real-Time Network to devices such as cell phones and personal digital assistants. Send an e-mail to streammail@usgs.gov with a USGS station number in the subject line and after a few minutes you will receive an e-mail with the most recent real-time stage and streamflow data.

\section{ACKNOWLEDGMENTS}

The insightful technical comments of Adam Slutsky and Carl Andreassen of the Somerset County Division of Engineering are gratefully acknowledged.

\section{REFERENCES CITED}

Dunne, Paul, and Velnich, A.J., 1994, Development, installation, and operation of a flood-monitoring system in Somerset County, New Jersey: U.S. Geological Survey Open-File Report 94-65, 23 p.

Somerset County Department of Public Works, 1996, Somerset County Flood Information System: Operations manual: Somerville, N.J., Somerset County Department of Public Works, Division of Engineering, September 1996, 16 p.

\section{by Heidi L. Hoppe}
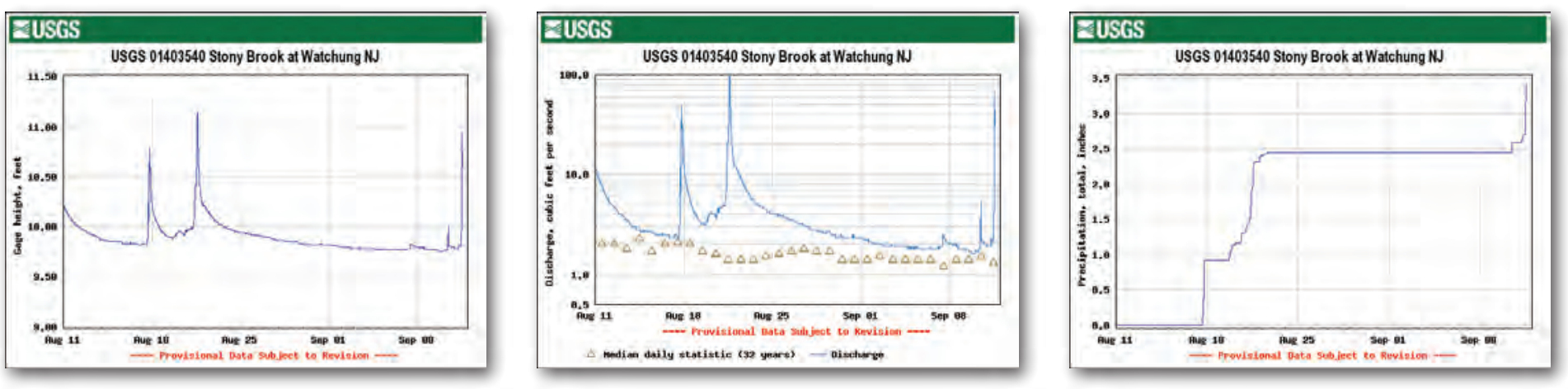

Figure 4. Example of hydrographs that can be viewed and printed from the "Real-Time Data" web page.

For more information, contact:

New Jersey Water Science Center

U.S. Geological Survey

810 Bear Tavern Rd., Suite 206

West Trenton, NJ 08628

On the web: http://nj.usgs.gov/

E-mail: DC_NJ@usgs.gov
Cooperating agency:

Somerset County Division of Engineering

20 Grove Street

Somerville, NJ 08876

Phone: (908) 231-7024 